\title{
Withholding consent to conjugal relations within child marriages in colonial India: Rukhmabai's fight
}

Kanika Sharma, SOAS University of London

\begin{abstract}
Married at the age of eleven, Rukhmabai refused to go and live with her husband who had filed a suit for restitution of conjugal rights against her in 1884. This paper analyses the transplantation of the notion of restitution of conjugal rights into Hindu personal law in India at a time when child marriage was rife and there was no minimum age of marriage. Within this context Rukhmabai's case symbolises an important interjection in its attempt to posit lack of consent to an infant marriage as a defence against suits for restitution of conjugal rights. This marked a shift from female consent being understood as a question of physical maturity alone, to a claim of intelligent consent and the capacity to withhold such consent within an unconsummated marriage arranged in the girl's infancy. While analysing these notions of consent within colonial law the paper also closely scrutinises Rukhmabai's public writings to recover one of the earliest published Indian female views on the need for marital consent.
\end{abstract}

XXXXXX

As the incipient Indian national movement gained strength, many political claims came to be made on, and through, the body of the native female. Her passive body came to be marked by issues of national and familial duty, racial difference, patriarchy, colonial 
This is the accepted manuscript of an article published by Cambridge University Press in Law and History Review. Available on line: https://doi.org/10.1017/S0738248020000024

Accepted version downloaded from: http://eprints.soas.ac.uk/32594/

governance, religious reform, and law, amongst others. A multitude of voices jostled to speak on her behalf, while effectively excluding her from the public discourse. Firstly, the latenineteenth century variant of Indian nationalism rejected its earlier policy of bringing about social reform for women through the legislative intervention of the colonial state. Where once reformists had actively sought the help of the state on issues such as Sati and widow remarriage, now the nationalist position firmly located the woman's question in the domain of the private sphere and outside the purview of the state.1 Secondly, the colonial authorities sought to derail this nationalism and deny Indians self-government due to their "lack of civilisation" as evidenced by the poor treatment of the native women.2 And lastly, from the late nineteenth century onwards, British women's rights activists too sought to speak on behalf of Indian women, and emphasise the developmental difference between European and Indian women, in order to further their own agenda of gaining greater rights.3

1 For instance, see Partha Chatterjee, "Colonialism, Nationalism, and the Colonialized Women: The Contest in India," 16, no. 4 (1989) American Ethnologist:622. For an analysis of nationalism in the context of age of consent see Tanika Sarkar,Hindu Wife, Hindu Nation: Community, Religion and Cultural Nationalism (Ranikhet: Permanent Black, 6th impression 2017).

2 For instance, see Janaki Nair, Women and Law in Colonial India (New Delhi: Kali for Women, 1996).

3 For a detailed analysis of this relation see Antoinette Burton, Burdens of History: British Feminists, Indian Women, and Imperial Culture, 1865 - 1915 (London: University of North Carolina Press, 1994). 
This is the accepted manuscript of an article published by Cambridge University Press in Law and History Review. Available on line: https://doi.org/10.1017/S0738248020000024

Accepted version downloaded from: http://eprints.soas.ac.uk/32594/

Starting at the end of the nineteenth century, the debate around raising the female age of consent in India epitomised the central, but forcibly mute, position occupied by native women in the colonial milieu of the time. 4 One notable exception was Rukhmabai Raut, a Maharashtrian Hindu woman, who had been married at the age of eleven, and who had since resisted her marital fate and refused to live with her husband. When Rukhmabai's husband filed a suit for restitution of conjugal rights against her at the Bombay High Court, she defended herself and spoke out against the ills of child marriage, through the pages of a wellknown national daily The Times of India. This article uses the Rukhmabai case to analyse the start of the age of consent debate in India which eventually led to the Age of Consent Act of 1891.

In the early years of the age of consent debate in India "consent" was defined in a very narrow way and centred almost entirely around the supposed physical maturity of the girl. Within the legal sphere there was no talk of age of consent for males; and for females the age of minority was linked to the purpose of the sexual contact, with the age of consent for non-marital sexual relations (including prostitution) being set at a higher age than those within the confines of marriage. In this India was far from unique, as most countries of the British Empire, including Britain, set a higher age of consent for sexual relations outside of marriage. What was particular to India, however, was the fact that in all these instances and in all the discourses surrounding the age of consent debate -- the medical, the legal, the reformist, the religious and the nationalist -- the word "consent" was limited to signifying a

\footnotetext{
4 For remarkable exceptions and a discussion on the emergence of feminism in India, especially in the Bombay Province, see Padma Anagol, The Emergence of Feminism in India
} 1850-1920 (Oxford: Routledge, 2016). 
This is the accepted manuscript of an article published by Cambridge University Press in Law and History Review. Available on line: https://doi.org/10.1017/S0738248020000024

Accepted version downloaded from: http://eprints.soas.ac.uk/32594/

physical capacity, a supposed maturity after which the female body could sustain intercourse without coming to physical harm. As Tanika Sarkar notes: "So it was her body that signified consent, and it was her body that would enjoy legal immunity till then. The protected person was nothing more than a protected body. Personhood for her did not extend to anything beyond her sheer physical existence."5

Within this context, Rukhmabai's early intervention into the debate is worthy of consideration, for she articulated not just an idea of the importance of the personal consent of a bride for her own marriage but became the first Hindu woman to write about this publicly.

This paper seeks to analyse the ways in which consent came to be understood in cases for restitution of conjugal rights in colonial India. In the first section we get acquainted with the facts of the Rukhmabai case and briefly examine the social context in which the case emerged. We then turn to the legal sphere to analyse how the notion of suits for restitution of conjugal rights was transplanted from within English ecclesiastical law to Hindu personal law in India. Far from acting in the interests of "justice, equity, and good conscience", this legal transplant severely restricted the marital rights of Hindu women. Within this context Rukhmabai's case symbolises an important interjection, for it attempted to posit lack of consent to an infant marriage as a defence against suits for restitution of conjugal rights. This marked a shift from female consent being understood as a question of physical maturity alone, to a claim of "intelligent consent" 6 and the capacity to withhold such consent within an

\footnotetext{
5 Sarkar, Hindu Wife, Hindu Nation, 244.

6 I use the term intelligent consent here as it was used in the draft penal code of India to denote consent given when a person is able to "understand the nature and consequences" of
} 
This is the accepted manuscript of an article published by Cambridge University Press in Law and History Review. Available on line: https://doi.org/10.1017/S0738248020000024

Accepted version downloaded from: http://eprints.soas.ac.uk/32594/

unconsummated marriage arranged in the girl's infancy. While analysing these notions of consent within colonial law, the paper also closely scrutinises Rukhmabai's writings to recover one of the earliest published female views on marital consent in India.

Introducing the Rukhmabai case

When it comes to the historical analysis of the age of consent debate in India, the Rukhmabai case is amongst one of the two most scrutinised cases.7 Described as "the most famous of the conjugal rights cases of the nineteenth century" 8 , the case and the responses it elicited from the Indian public and the colonial state have been thoroughly examined by Sudhir Chandra.9 The case has also benefitted from close scrutiny through several academic lenses and has variously been part of the studies on militant nationalism, history of social reform, the relation between Western and Indian women's rights activists, the marital rights of Indian wives in colonial India, and the failed promises of British imperialism.10

that to which she gives consent. A Penal Code prepared by the Indian Law Commissioners (Calcutta: The Governor General of India in Council, 1837), 6.

7 The other case was that of Phulmonee Dasi, discussed by Tanika Sarkar in this volume. 8 Jim Masselos, "Sexual Property/Sexual Violence: Wives in Nineteenth Century Bombay," 12, no. 2 (1992) South Asia Research: 84.

9 Sudhir Chandra, Enslaved Daughters: Colonialism, Law and Women's Rights, 2nd edn (New Delhi: Oxford University Press, 2011).

10 Sarkar, Hindu Wife, Hindu Nation, especially Chs 6 and 7; Masselos, "Sexual Property/Sexual Violence"; Charles Heimsath, Indian Nationalism and Hindu Social Reform (Princeton: Princeton University Press, 1964); Meera Kosambi, “Girl-Brides and Socio-Legal 
Rukhmabai's case captured public attention in her time, and has attracted academic scrutiny since, for a few different reasons: Firstly, as mentioned earlier, it became a site of mobilisation for an incipient Indian nationalism. Secondly, Rukhmabai’s trial marks a departure from earlier cases of restitution of conjugal rights, because it became the first case to frame the issue in terms of female intelligent consent and sought to challenge the relation between age and consent as understood in Indian colonial marital law. Lastly, unlike the largely silent Hindu wives who had so far been the defendants in suits for restitution of conjugal rights, Rukhmabai chose to articulate her discontent with the law repeatedly in the public sphere. Her letters to the domestic newspaper The Times of India and The Times in Britain provided first-hand accounts of the plight of a woman married during her childhood to a man she would never have chosen for herself. Her trial and her writings captured the imagination of reformers at home and abroad, with people in India and Britain collecting funds to defray her defence costs.11 Such was the furore around the case, that everyone from the Viceroy of India to Queen Victoria expressed a view on the trial.

Change: Age of Consent Bill (1891) Controversy”26, no. 31 (1991) Economic and Political Weekly 1857-68; Sudhir Chandra, "Whose laws? Notes on a legitimising myth of the colonial Indian state," 8 (1992) Studies in History 187-211; Antoinette Burton, "From Child Bride to 'Hindoo Lady': Rukhmabai and the Debate on Sexual Respectability in Imperial Britain,” 103 (1998) The American Historical Review 1119-46; Anagol, The Emergence of Feminism in India 1850-1920, especially Ch 6.

11 The most prominent of such organisations was the Rakhmabai Defence Committee (Rakhmabai Surakshana Samiti) founded by Rukhmabai's Indian and European supporters. 
This is the accepted manuscript of an article published by Cambridge University Press in Law and History Review. Available on line: https://doi.org/10.1017/S0738248020000024

Accepted version downloaded from: http://eprints.soas.ac.uk/32594/

While the various historical analyses of the case have sought to provide its socio-legal context, the transplantation of suits for restitution of conjugal rights into the jurisdiction of native marriages, especially Hindu marriage law, has not been studied in depth.12 A glance at the cases that established such suits reveals the piecemeal basis on which this process was undertaken. At the heart of the Rukhmabai case was the relation between intelligent consent, or lack thereof, and suits for restitution of conjugal rights. This relation gave rise to a series of interrelated questions: Can suits for restitution of conjugal rights be enforced against wives who had not given "personal consent" to their marriage? Was the consent of the bride or the groom a requirement for a valid Hindu marriage? And if so, what should be the age of consent? And how should this age of consent be defined -- should it take into account only the physical maturity of the girl, or should it be fixed at an age when she could reasonably be expected to give intelligent consent to her marriage?

The case of Dadaji Bhikaji v Rukhmabai 13 was a suit for restitution of conjugal rights brought forward by Bhikaji in the Bombay High Court in 1884 after several unsuccessful attempts to convince his wife and her family that the couple should cohabit. In the early 1870s, when a pre-pubescent Rukhmabai was only 11 years old, she was married to the 19year-old cousin of her step-father, Bhikaji. According to the Hindu customs of the time, she was to live with her natal family till the age of puberty, when the garbadhan ceremony would be performed. At this point, the marriage would be immediately consummated, and she would move to her marital home.

12 With the exception of Masselos and Anagol, both of whom concentrate on Bombay. 13 Dadaji Bhikaji v Rukhmabai, ILR 9 Bom 529 (1885) 
This is the accepted manuscript of an article published by Cambridge University Press in Law and History Review. Available on line: https://doi.org/10.1017/S0738248020000024

Accepted version downloaded from: http://eprints.soas.ac.uk/32594/

Rukhmabai's step-father, Dr Sakharam Arjun, was a well-known reformist in Bombay, who was against the early consummation of child marriages. At his behest, the families reached an agreement where-in instead of Rukhmabai joining Bhikaji’s household, the latter was to live with her family and receive an education. Never keen on his studies, soon after the marriage Bhikaji contracted tuberculosis which allowed him to neglect his education and upon recovery he went off to live with his uncle. It is while living in the latter's house that he decided to approach the High Court.

When Bhikaji filed the suit, Rukhmabai was 22 years old, and considered well past the age at which Hindu girls were to cohabit with their husbands. Many have argued, and certainly Rukhmabai herself believed, that when Bhikaji brought the suit against Rukhmabai, he was not actually expecting her to answer him in court. He had hoped that the public scandal that ensued, and pressure from the community, would be enough to force the hand of Rukhmabai and her family.14 However, this was not to be. Between 1884 and 1888 Rukhmabai and Bhikaji returned time and again to the Bombay courts. Rukhmabai's corner was fought by the Advocate General (AG), FL Latham, and the defence counsel -- KT Telang and JD Inverarity; and Bhikaji was represented by Macpherson, Vicaji and Mankar.

Rukhmabai's trial departed from previous cases for restitution of conjugal rights in two crucial ways. Firstly, the issue of the lack of a wife's consent to a marriage performed in her childhood was sought to be used as a defence against a suit for restitution of conjugal rights. Secondly, the AG and the defence counsel sought to discredit such suits within Hindu law. They attempted to do so by using a two-pronged approach of highlighting the foreign

14 Rukhmabai, “A Jubilee for the Women of India,” The Times, 9 April 1887, 8. 
This is the accepted manuscript of an article published by Cambridge University Press in Law and History Review. Available on line: https://doi.org/10.1017/S0738248020000024

Accepted version downloaded from: http://eprints.soas.ac.uk/32594/

nature of such suits and the fact that they were unsupported by any authority within Hindu law; and by stressing the distinction between "restitution" and "institution" of conjugal rights. They argued that even if suits for restitution of conjugal rights had lately come to be accepted within Hindu law, in an unconsummated marriage such as Rukhmabai's the courts were being asked to act outside their authority, for they were not enforcing "restitution" but in fact ordering the "institution" of conjugal rights.

In September 1885, Justice Pinhey of the High Court found in favour of Rukhmabai. He held that since she had never lived with her husband, Bhikaji was not pleading for the "restitution" of conjugal rights, but their "institution", an idea for which the judge could not find any English authority. However, Rukhmabai's victory was short-lived and in early 1886 the Bombay Appeal Court reversed Pinhey's decree by holding that Hindu marriages did not require the consent of the bride or the groom and returned the case to the High Court for a decision on the merits of the case. At its second hearing at the High Court in 1887, the judgment went in favour of Bhikaji, with Rukhmabai being ordered to pay the costs of both parties for the original case and to go to her husband or face six months imprisonment. Finally, a compromise was achieved during the second appeal in July 1888, with Bhikaji agreeing to forgo his conjugal rights for a considerable monetary payment. Before we proceed to our analysis of the Rukhmabai case, it is important to turn our attention to the legal notion of restitution of conjugal rights and how it came to be applied to Hindu marriages in India.

Consent, conjugal rights, and the Hindu marriage 
The notion of restitution of conjugal rights is indelibly linked to the idea of consent, for through a suit for restitution of conjugal rights a spouse can approach the courts to force their unwilling spouse to cohabit with them against their consent. When Bhikaji approached the courts, suits for restitution of conjugal rights were a recent legal transplant imported to India from English ecclesiastical law. English law, following from traditional ecclesiastical law, mandated that in order to be valid, a Christian marriage required the consent of the bride and the groom though not necessarily the consummation of the marriage itself -- consensus non concubitis facit maritorium. 15 Since the spouses had consented to the marriage itself, it was assumed that they had also consented to cohabitation and marital relations within the marriage. In fact, where one of the parties was deemed not to have consented because they were under the age of discretion, the marriage could only be validated by cohabitation and consummation.16 And as valid Christian marriages were seen to be irrevocable, it followed that the courts were willing to send a reluctant husband or wife to live with their spouse against the wishes of the former. This raised two important questions for the suitability of restitution of conjugal rights within native marriages: Firstly, in a country where people were married before they reached the age of majority, could they be said to have consented to a marriage arranged by their parents? Secondly, as per Hindu tradition the wedding ceremony and the consummation of the marriage were separate rituals, often separated by years. If the bride or the groom of an infant marriage, at a later date, refused to either cohabit with their spouse, or consummate the marriage, could the courts force them to perform either act? That is to say, could courts "institute" conjugal relations where none had previously existed?

\footnotetext{
15 A v B (1868) LR 1 P\&D 559, 562.

${ }_{16}$ Corbet's Case (1599) 7 Co Rep 44a quoted in Joseph Jackson, “Consent of the Parties to Their Marriage” 14 (1951) The Modern Law Review 1-26, 23.
} 
Between 1800 and 1856 the Recorder's Court of Bombay had listed eight such cases for restitution of conjugal rights in the Mayor's Courts (operational till 1823) and later the Supreme Court of Bombay. None of these cases involved Hindu couples.17 As Padma Anagol further notes, seven out of these eight cases had been brought by wives insisting that their husbands should either take them back or pay them alimony instead. All these cases had been brought on the ecclesiastical side of the Bombay Courts, and the suits for restitution of conjugal rights only came to be officially recognised in the native religions, when a Parsi husband challenged the Ecclesiastical Court's jurisdiction over Parsis in 1856.

The decades before Rukhmabai's case had seen a slow incursion of the idea of restitution of conjugal rights into Hindu marital law, by way of judgments given in the personal laws of the other native religions of the country. In the first such recorded case, brought by a deserted Parsi woman against her husband, the Privy Council had held that while the ecclesiastical jurisdiction of the courts could not be extended to non-Christians there was no reason why such suits could not be entertained on their civil side.18 Ten years later in Moonshee Buzloor Ruheem v Shumsoonnissa Begum19, brought forward by a Muslim man against his wife, the Privy Council restricted itself to rights within a Muslim marriage. The Council held that the civil courts in India could decide on cases of restitution of conjugal rights when approached by a Muslim husband, and that the husband could obtain the restitution of conjugal rights without the consent of the wife. Crucially, however, the

${ }_{17}$ Padma Anagol, The Emergence of Feminism in India 1850-1920, 185.

18 Ardaseer Cursetjee v Perozeboye, 6 MIA 348 (PC) (1856)

19 Moonshee Buzloor Ruheem v Shumsoonnissa Begum, 9 MIA 551 (PC) (1867) 
This is the accepted manuscript of an article published by Cambridge University Press in Law and History Review. Available on line: https://doi.org/10.1017/S0738248020000024

Accepted version downloaded from: http://eprints.soas.ac.uk/32594/

Privy Council did not give a final decree in the case and instead remitted it to the High Court for a retrial.

Under Indian colonial law, Muslim marriages were treated as civil contracts and distinguished from Hindu marriages which were regarded as "sacrament rather than law".20 Since the validity of contracts depended upon the consent of the contracting parties establishing suits for restitution of conjugal rights within Muslim marriages did not seem as much of a leap as extending the same idea to infant Hindu marriages too. In fact, the Privy Council itself was reluctant to posit any rules which would be applicable to marriages in all religions. "For since the rights and duties resulting from the contract of marriage vary in different communities; so, especially in India, where there is no general marriage law, they can be only ascertained by reference to the particular law of the contracting parties." 21 However, it wasn't long before suits for restitution of conjugal rights were being recognised within Hindu marriages as well.

In the very year after in Moonshee Buzloor Ruheem, the Appellate Court in Bombay seemed to assume that a suit for restitution of conjugal rights would ordinarily lie among the Hindus too.22 However, the court held that it would be cruel to force a wife to live with a man who had a "loathsome disease". Since in this case the husband suffered from leprosy and syphilis the wife was able to use his disease as a defence against the suit.

20 In this regard, colonial law regarded Hindu marriages as being closer to the irrevocable Christian marriages.

21 Moonshee Buzloor Ruheem v Shumsoonnissa Begum, 610

22 Bai Prem Kuvar v Bhika Kallianji, 5 Bom HCR 259 (1868) 
The cases discussed so far reveal the slow intrusion of the idea of restitution of conjugal rights into the native religions of India. While legal transplants in native personal law were not a new phenomenon, they had so far been severely restricted. The colonial administration in India had largely refrained from interfering in religious laws and customs of the native population. This principle had been laid out in Rule 23 of the Judicial Plan of Warren Hastings of 1772, which noted that in "all suits regarding the inheritance, marriage, caste and other religious usages, or institutions, the laws of the Koran with respect to Mohamedans and those of the Shaster with respect to Gentoos shall be invariably adhered to." This plan had laid the foundations of the religion based personal law system in colonial India, and the promise of non-interference in native religions had been reiterated in the Queen's Proclamation of 1858. It is important to note here that the policy of non-interference was not necessarily a sign of respect towards the native religions. More often than not, it was simply a by-product of the state's desire to maintain social order to enable it to fulfil its supreme colonial objective of economic extraction.23 In fact, when the state did intervene in the domain of religious personal laws, it took great pains to establish that the "reform" was only carried out against "deviant" customs in order to return to authentic scriptural norms.24 In the sphere of personal law, then, the colonial state strongly allied itself with the prevailing

23 Lata Mani, Contentious Traditions: The Debate on Sati in Colonial India (London: University of California Press, 1998), 13.

24 Tanika Sarkar and Sumit Sarkar, 'Introduction' to Women and Social Reform in Modern India, Sumit Sarkar and Tanika Sarkar (eds), (Bloomington, IN: Indiana University Press, 2008), 3; and Lata Mani makes the same point in the context of Sati in Contentious Traditions, 15. 
This is the accepted manuscript of an article published by Cambridge University Press in Law and History Review. Available on line: https://doi.org/10.1017/S0738248020000024

Accepted version downloaded from: http://eprints.soas.ac.uk/32594/

orthodoxy.25 This decision to appease the orthodoxy allowed the government to emphasise the civilizational difference between the metropole and the colony, thus justifying the need for their own presence in the colony and their stated civilising mission.26 At the same time, the colonial courts' preference for scripture ensured that on any issue, both the arguments for and against reform had to be made through scripture.27

Though rarely utilised, the colonial state did have one key tool at its disposal to instigate reform in the sphere of personal laws. If the religious texts did not give specific directions on an issue, the courts could adjudicate on the basis of "justice, equity and, good conscience" under sections 60 and 93 of Elijah Impey's Judicial Regulations of 1781. However, as we shall see below, and as Justice Pinhey noted in Rukhmabai's trial, the introduction of restitution of conjugal rights in Hindu personal law went against every principle of justice and equity.

It is also interesting to note that the transplantation of the notion of restitution of conjugal rights within the native religions, including within Hindu marital law, was met with little resistance from Indian men. Already enjoying a privileged position within the Hindu

25 Mrinalini Sinha, Colonial Masculinity: The 'manly Englishman' and the 'effeminate Bengali' in the late nineteenth century (Manchester: Manchester University Press, 1995), 141.

26 Ashwini Tambe, "The State as Surrogate Parent: Legislating Nonmarital Sex in Colonial India, 1911-1929," 3, no. 2 (2009) The Journal of the History of Childhood and Youth 39: 416.

27 Tanika Sarkar and Sumit Sarakar, 'Introduction', 3. 
This is the accepted manuscript of an article published by Cambridge University Press in Law and History Review. Available on line: https://doi.org/10.1017/S0738248020000024

Accepted version downloaded from: http://eprints.soas.ac.uk/32594/

marriage, including the option of polygamy, not only did such suits not add any new burdens on him, they also gave him an extra tool to ensure that his deserting wife could be returned to his control.

The three cases discussed above mark the extension of restitution of conjugal rights to the Parsi, Muslim and Hindu religions, but in each case this extension was only theoretical for none of them actually issued a decree for such restitution. A sudden shift towards not just recognising, but also enforcing, restitution of conjugal rights within Hindu marriages can be traced back to two cases heard by Justices Markby and Mitter at the Calcutta High Court on 9 January 1875 . The decisions of both of these cases had a strong impact on the Rukhmabai case.

The first case perhaps bears the strongest resemblance to Rukhmabai's case in matters of fact. In Kateeram Dokanee, the wife was a minor who had never lived with her husband, and their marriage was unconsummated when he had brought the suit for restitution of conjugal rights against her. 28 The wife and her family, in turn, denied that the marriage had ever taken place. This became the first case where the judges expressly articulated that a suit for restitution for conjugal rights would ordinarily lie amongst Hindus. They also held that the age of the wife at the time of marriage was no defence against such suits. Importantly for us, the issue of the wife's consent, or lack thereof, was not raised as a defence against the suit for restitution of conjugal rights. Instead, the case focused on whether a valid marriage had been performed, and if so whether the guardianship of a married minor girl would lie with her family or her husband, and the Court found for the latter. Justice Markby stated: "The

28 Kateeram Dokanee v Mussamut Gendhenee, 23 WR 178 (1875) 
This is the accepted manuscript of an article published by Cambridge University Press in Law and History Review. Available on line: https://doi.org/10.1017/S0738248020000024

Accepted version downloaded from: http://eprints.soas.ac.uk/32594/

marriage of an infant being under the Hindoo law a legal and complete marriage, the husband, in my opinion, has the same rights as in other cases to demand that his wife shall reside in the same house as himself." The Court went on to stipulate that in the case of a minor wife the husband must show that the wife would be placed in the care of a female member of his family. However, once again, the Court did not give a decree of restitution of conjugal rights but remanded it to the Judicial Commissioner to decide upon the validity of the marriage.

In the second case, Gatha Ram Mistree29, the same judges did uphold a decree for restitution of conjugal rights in a Hindu marriage. While doing so, Markby and Mitter scrutinised the nature of enforcement of the decree that they could issue in the name of restitution. The issue of enforcement, too, had important consequences for Rukhmabai's case, for Justice Farran's decision to threaten her with six months' imprisonment under s260 of The Code of Civil Procedure 1882 unless she obeyed the decree for restitution propelled Rukhmabai's case to a level of fame not seen in a case for restitution of conjugal rights in India before.

The nature of enforcement of such decrees had first been debated in depth in a Muslim marital case in 1866.30 There Justices Macpherson and Jackson of the Calcutta High Court had held that the courts could only enforce a suit against the wife through her imprisonment, or the attachment of her property, or both. In the same case, Justice Seton-Karr had dissented, and had strongly argued that the wife could be delivered bodily to the husband

29 Gatha Ram Mistree v Moohita Kochin Atteah Domoonee, 14 BLR 298 (1875)

30 Chotun Bebee v Ameer Chand, 6 WR 105 (1866) 
This is the accepted manuscript of an article published by Cambridge University Press in Law and History Review. Available on line: https://doi.org/10.1017/S0738248020000024

Accepted version downloaded from: http://eprints.soas.ac.uk/32594/

in execution of the decree. Following the majority ruling, in 1871 section 200 of the Code of Civil Procedure (CCP) of India made a distinction between suits for "decree of moveable property" more generally and cases involving conjugal rights specifically.31 While imprisonment and fines were to be attached to individuals who did not follow the court's decree, an exception was to be made for disobedience of decrees for restitution of conjugal rights. And the Act specifically noted that "A decree for the plaintiff, in a suit by a husband for restitution of conjugal rights, ought to be declaratory only, and to be enforced, in case of disobedience, by attachment, and not by ordering the lady to be given up as a 'specific moveable' under this section.”32

Returning to Gatha Ram Mistree we find that while the judges were willing to issue a decree for restitution of conjugal rights against the wife's consent, they were unwilling to allow a husband to have forceful possession of a non-consenting wife. Here, a full decade before Farran's judgment in the Rukhmabai case, the judges had argued that ordering the wife to be delivered bodily to the husband in execution was "shocking to our feelings of humanity" and "universally condemned" and even the alternative of forcing a wife to comply through threat of fines or imprisonment was "generally repudiated" 33 . Based on this, they reiterated that a decree for restitution could only be declaratory in nature.

31 As noted above, later the CCP 1882 included a separate section for decrees of restitution of conjugal rights $-\mathrm{s} 260$.

32 LP Delves Broughton, The Code of Civil Procedure being Act VIII of 1859, 4th edn (Calcutta: Thacker, Spink and Co., 1871).

33 Gatha Ram Mistree v Moohita Kochin Atteah Domoonee, 304 
This is the accepted manuscript of an article published by Cambridge University Press in Law and History Review. Available on line: https://doi.org/10.1017/S0738248020000024

Accepted version downloaded from: http://eprints.soas.ac.uk/32594/

A year later, going against precedent and the CCP, Justices Melvill and West of the Appellate Court in Bombay held that in the absence of "legal cruelty on the part of her husband or his relations" a woman must be physically returned to her husband.34 In doing so, in a single blow the judges had reduced the non-consenting wife to, in the words of Justice Pinhey, the status of a "horse or bullock" whose body could belong to another against her own will.35 Following this, the CCP of 1877 no longer mandated that decrees of conjugal rights be only declaratory in nature.

For its examination of the early history or restitution of conjugal rights cases in Hindu law, this paper has only focused on cases that have been reported. In a common law system such as that of India, a survey of the leading cases may not be the most comprehensive methodology, but it certainly reveals the most significant judicial manoeuvres that have shaped the field. 36 In the selected period of examination, i.e. the run up to the Rukhmabai case, there was a perceptible increase in such cases in the various High Courts in India from

34 Yamunabai v Narayan Moreshivar Pendse, 1 ILR Bom 164 (1876), 174

35 "Suit for the Restitution of Conjugal Rights: Dadajee Bhikajee vs Rukhmibai," The Times of India, 25 September 1885, 5. (Hereafter TOI).

36 Mitra Sharafi, "The semi-autonomous judge in colonial India: Chivalric imperialism meets Anglo-Islamic dower and divorce law," 46 (2009) The Indian Economic and Social History Review 57-81, 60. 
This is the accepted manuscript of an article published by Cambridge University Press in Law and History Review. Available on line: https://doi.org/10.1017/S0738248020000024

Accepted version downloaded from: http://eprints.soas.ac.uk/32594/

the mid-1870s, but there was little to differentiate between the approach taken by them on the issue of restitution on conjugal rights within Hindu marriages.37

Here, the judgments of the Privy Council are reflective of the attitude of the lower courts as well. In suits for restitution of conjugal rights, most judges, such as Sir James Colvile, were eager to uphold the "rights" of the "stronger sex" 38 and hastened to find in favour of the husband. They did so even while recognising that there was a strong desire for social reform within the Hindu community. For instance, even when the courts recognised that not all Hindus supported infant marriage, and the Privy Council went so far as to describe it as a rite that "so many philosophical Hindus consider one of the most objectionable of their customs" 39 , they still refused to ally with the reformists. This was not entirely surprising, for as we have seen above in all big issues of socio-legal reform, including in this case child marriage, the policy of the colonial government was to favour the more orthodox religious groups rather than the reformists. As Sarkar argues, in the face of "bitter struggles with Victorian feminism at home" the judges in India as well as the Privy Council were only too willing to foster the "patriarchal absolutism" within the native legal system. 40 This led to some compromises that were unique to native marriages: For instance, a Hindu or Muslim woman could not use her husband's second marriage (even if it was against

\footnotetext{
37 At the turn of the century Justices Ameer Ali and Brett come to the same conclusion in their examination of existing case law presented as part of their judgment in Surjyamoni Dasi v Kali Kanta Das ILR 28 Cal 37 (1901).

38 Moonshee Buzloor Ruheem v Shumsoonnissa Begum, 610.

39 Jumoona Dassya Chowdhrani v Bamasoonderai Dassya Chowdhrani, 3 IA 72 (1876), 78. 40 Sarkar, Hindu Wife, Hindu Nation, 201.
} 
This is the accepted manuscript of an article published by Cambridge University Press in Law and History Review. Available on line: https://doi.org/10.1017/S0738248020000024

Accepted version downloaded from: http://eprints.soas.ac.uk/32594/

her wishes) as a defence against a suit for restitution of conjugal rights, 41 but could defend against it if he brought a prostitute to live within the household.42

However, while the various High Court benches largely remained in harmony and allied with the Hindu orthodoxy, from time to time, individual judges expressed a divergent view towards a husband's right to demand restitution of conjugal rights when faced by a nonconsenting wife. These judges epitomised what Mitra Sharafi has previously labelled as the 'semi-autonomous' judge; they attempted to find in favour of the non-consenting Hindu wife by 'undermining the colonial legislation and personal law treatises they were expected to apply.' 43 In the cases we have discussed above, Justices Mitter and Markby of the Calcutta High Court certainly seemed to be taking this approach in Gatha Ram Mistree, and Justice Pinhey attempted to do the same in the Rukhmabai case as we shall see below.44

Returning to the central focus of this paper, we see that from time to time, the issue of consent, or the lack thereof, was sought to be raised as a defence in suits for restitution of conjugal rights within Hindu marriages. However, before Rukhmabai the cases focused on the lack of consent of the natural guardian of the infant bride and paid no heed to the consent, or its lack, of the two parties to the marriage. Even in this, the courts were rather circumspect

41 Arumugam v Tulukanam, ILR 7 Mad 187 (1883)

42 Lalla Gobind Pershad v Dowlut Butee, 14 WR 451 (1870)

43 Sharafi, "The semi-autonomous judge in colonial India".

44 Following Sharafi, who in turn borrows from Hendrik Hartog, I must highlight that even when judges found in favour of the wives, they were not necessarily doing so in order to follow a 'feminist agenda'. 
This is the accepted manuscript of an article published by Cambridge University Press in Law and History Review. Available on line: https://doi.org/10.1017/S0738248020000024

Accepted version downloaded from: http://eprints.soas.ac.uk/32594/

and usually limited their scrutiny to whether the marriage had been solemnised without fraud or force. If there was no evidence of either, then the doctrine of factum valet applied, and the marriage was deemed to be irrevocable. 45

Through our survey of cases from different parts of India, we can see how quickly the idea of restitution of conjugal rights within Hindu marriages had come to take root within the colonial courts after the first decree awarded to a Hindu husband in 1875 in Gatha Ram Mistree. As Ardaseer Cursetjee demonstrates, often such suits had little to do with a desire for cohabitation and were instead means of securing financial relief. Even in England, where such suits originated, it was not uncommon for women to bring these suits against their husbands as a measure to gain ancillary relief and secure a maintenance from a reluctant husband. This was a circumstance recognised by both the plaintiff wives 46 and the courts 47 alike. In fact, the case that spurred the end of suits for restitution of conjugal rights in England through the Matrimonial Causes Act 1884 was one such case brought by a woman against her husband.48 Thus, it would be incorrect to view suits for restitution of conjugal rights as patriarchal tools that always limited the rights of non-consenting wives, as husbands were very often the defendants in such cases. According to figures cited by Anagol, between 1881 and 1885, 727 suits for enforcing decrees for restitution of conjugal rights came before the civil courts in the Bombay Presidency, and a further eighty-one suits for the dissolution of marriages. She notes: "Most of the former were by women or by guardians on behalf of

45 Brindaban Chandra Kurmokar v Chandra Kurmokar, ILR 12 Cal 140 (1885)

46 For instance, see Hope v Hope, 164 ER 644 (1858)

47 For instance, see Marshall v Marshall, 5PD 19 (1879)

48 Weldon v Weldon, 9 PD 52 (1883) 
This is the accepted manuscript of an article published by Cambridge University Press in Law and History Review. Available on line: https://doi.org/10.1017/S0738248020000024

Accepted version downloaded from: http://eprints.soas.ac.uk/32594/

young married girls." 49 These figures reveal that even in India women were actively seeking to use such suits for ancillary relief.50

In a reversal of the usual norm, many believed that Bhikaji's suit was also an attempt to garner monetary benefits. Due to the disparity in means between Rukhmabai and Bhikaji, it was argued that Bhikaji's suit for restitution of conjugal rights was not an attempt at cohabitation, but a bid to secure access to Rukhmabai's considerable wealth. Bhikaji admitted as much, in an "exposition" he published after the second High Court judgment.51

Returning to the Rukhmabai case

Rukhmabai's counsel and, indeed, Rukhmabai herself had highlighted Bhikaji’s paucity of funds and his general unsuitability to the Court. In her written statement to the Bombay High Court, Rukhmabai listed the reasons why she refused to live with her husband, namely: his inability to provide for proper maintenance and residence for the couple; his illhealth; and the character of the people with whom he lived.52

49 Anagol, "Feminist Inheritances and Foremothers: The beginnings of Feminism in Modern India” 19 (2010) Women's History Review 523-46, 537.

50 In fact, Rukhmabai's counsel's attempt to discredit such suits for restitution of conjugal rights within Hindu marriages, was discouraged by some on the grounds that it would restrict the rights of abandoned wives in the future.

51 Dadaji Bhikaji, An Exposition of Some of the Facts of the Case of Dadaji v Rakhmabai (Bombay: Advocate of India Steam Press, 1887) 2.

52 (1885) ILR 9 Bom 529, 531. 
However, the case did not hinge on finances or the incompatibility of the couple, but the question of consent and its centrality to the idea of restitution of conjugal rights. In the first instance, this defence was posited simply -- as stressed by the AG, Latham, Rukhmabai had given "no personal consent" to her marriage with the plaintiff.53 This absence of consent was not unique to this case, for the objection could be extended to all cases of infant marriages within Hinduism. Thus, perhaps in order to circumvent protests by the Hindu orthodoxy, and keeping in mind the adverse decision in Kateeram Dokanee, Latham did not question the validity of Rukhmabai's marriage, but restricted himself to the issue of the enforceability of suits for restitution of conjugal rights within Hindu marriages that were conducted while the wife was a minor. Bhikaji's counsel in turn argued that Hindu marriage was not a contract but a religious duty and therefore consent was immaterial. They further hinted that Rukhmabai's written statement revealed that Rukhmabai's counsel had not previously thought of using lack of consent as a defence, and that if they wanted to use Bhikaji's alleged lack of funds as a defence then the burden of proof was on them.

On 21 September 1885, without giving the defence counsel a chance to plead their case, Justice Pinhey of the Bombay High Court found in favour of Rukhmabai. He noted that suits for restitution of conjugal rights were a creature of English law which had only recently been introduced in India, and already stood discredited in England. He then argued that such a suit "has no foundation in Hindu law" and expressed his regret that this legal transplant had ever been allowed, especially since recent cases and statute in UK had rendered them inoperative in their original jurisdiction. Pinhey also made his distaste for Bhikaji's plea clear: "The

53 (1885) ILR 9 Bom 529, 531. 
This is the accepted manuscript of an article published by Cambridge University Press in Law and History Review. Available on line: https://doi.org/10.1017/S0738248020000024

Accepted version downloaded from: http://eprints.soas.ac.uk/32594/

defendant, being now of full age, objects to going to live with the plaintiff, objects to allowing him to consummate the marriage, objects to ratifying and completing the contract entered into on her behalf by her guardians while she was yet of tender age. It seems to me that it would be a barbarous, a cruel, a revolting thing to do to compel a young lady under those circumstances to go to a man whom she dislikes, in order that he may cohabit with her against her will..." 54

By describing the forcible return of Rukhmabai to her husband as a barbarous, cruel and revolting thing to do, Pinhey certainly seemed to be alluding to the principles of justice, equity and good conscience to which he was bound. But as our examination of case law reveals, and the judge himself acknowledged, once suits for restitution of conjugal rights had been introduced into Hindu marital laws, as a colonial judge he was also bound by precedent, no matter how recently this precedent had been set. Thus restricted, Pinhey decided to take a very narrow reading of the case. He held that it would be a misnomer to call this case a suit for restitution of conjugal rights, for "restitution" implied that conjugal rights had already been established within the relationship. Since this marriage had never been consummated, he argued, Bhikaji was actually bringing forward a suit for "institution" of conjugal rights. Pinhey held that no English authority allowed for the institution of such rights and therefore he could not grant Bhikaji the decree that he sought. Lastly, Pinhey sought to make clear that Bhikaji's financial circumstances had not influenced his judgment, for "A poor man has as much right to claim his wife as a rich man to claim his." ${ }_{55}$

\footnotetext{
54 Dadaji Bhikaji v Rukhmabai (1885), 534

55 Dadaji Bhikaji v Rukhmabai (1885), 535
} 
This is the accepted manuscript of an article published by Cambridge University Press in Law and History Review. Available on line: https://doi.org/10.1017/S0738248020000024

Accepted version downloaded from: http://eprints.soas.ac.uk/32594/

Despite Pinhey's protestations, to a large degree the backlash to his judgment came to focus on the class difference between Rukhmabai and Bhikaji. Indeed, in the Court of Appeal, Latham pleaded that the Court should consider not just Rukhmabai's lack of consent to the marriage, but also "the poverty of the husband and his social position" in order to find in her favour.56 For those who supported Bhikaji, Rukhmabai's case was seen as threatening to the sanctity of Hindu marriage at large. For if the courts found in her favour, many other women could refuse to go and live with their husbands, who had no fault but that of poverty.

The biggest backlash, however, was against the idea that the absence of consent may allow a wife to shun a husband who had been chosen by her parents. Since the vast majority of Hindu marriages were performed before the girl had reached the age of puberty or displayed a capacity to give or withhold intelligent consent, who was to stop millions of Indian women from refusing to live with their husbands simply because they did not choose them? The Native Opinion was one of many Indian newspapers that attacked Pinhey's judgment. "His decision in fact amounts to saying that any Hindu wife might any day refuse to go to her husband. It is according to him enough if she says that she dislikes him. The learned Judge does not seem to have seen the consequences of his judgment. It goes to the root of the marital tie and is entirely subversive of the principles that have governed society for ages." 57

In March 1886, Bhikaji’s appeal against Pinhey’s ruling was heard by Chief Justice Sargent and Justice Bailey. At the Appellate Court, Latham supported Pinhey's judgment on

56 Dadaji Bhikaji v Rukmabai (1886) ILR 10 Bom 301, 307.

57 Native Opinion, 27 September 1885 quoted in Chandra, “Whose laws?”: 206. 
This is the accepted manuscript of an article published by Cambridge University Press in Law and History Review. Available on line: https://doi.org/10.1017/S0738248020000024

Accepted version downloaded from: http://eprints.soas.ac.uk/32594/

two grounds. Firstly, a suit for restitution of conjugal rights did not lie amongst Hindus. He did admit that in the previous ten years the Indian courts had recognised such cases, but he argued that while doing so they had erred in the application of Hindu law. Secondly, he argued that the current case was not one for "restitution" of conjugal rights and there was no English authority that allowed for the enforcement of the commencement of cohabitation or the "institution" of conjugal rights.58 Once again, the AG highlighted Rukhmabai's lack of consent to her marriage: "One circumstance is the fact of the marriage having taken place when the wife was incapable of giving a reasonable consent, the complete absence of consent on her part." 59

During this Appeal, Latham also attempted to highlight the incompatibility of Rukhmabai and Bhikaji, and it is clear that he held the former in high regard. While he described Bhikaji as "a block head with whom you could do nothing", and "a singularly sickly specimen of humanity, always getting sick", Rukhmabai was described as a "thoroughly cultivated woman, a friend of European ladies" who was not under the influence of her family in this case. 60

Rukhmabai's counsel, Telang, steered clear of the consent argument, accepted unquestioningly the validity of Rukhmabai's marriage and focused instead on the foreignness of such suits within Hindu marriage. This is not entirely surprising, because Telang, a

58 Dadaji Bhikaji v Rukmabai (1886), 303.

59 Dadaji Bhikaji v Rukmabai (1886), 307.

60 "Suit by a Hindoo for the Restitution of Conjugal Rights: Dadajee Bikajee vs Rukmibai," TOI, 19 March 1886, 6. 
This is the accepted manuscript of an article published by Cambridge University Press in Law and History Review. Available on line: https://doi.org/10.1017/S0738248020000024

Accepted version downloaded from: http://eprints.soas.ac.uk/32594/

recognised authority in Hindu law and later a judge of the Bombay High Court, had a conservative view of the Hindu marriage. In 1887, after the High Court had given its second judgment in this case, Telang explicitly stated that "Hindoo marriages are not consensual marriages at all" and that suits for restitution of conjugal rights should not be fought on grounds of consent, even in cases of child marriage.61

Returning to the Appellate Court in 1886 we find that Telang attempted to mount a simple defence for Rukhmabai, stating that within Hinduism there is "no suggestion of what is known as restitution." $62 \mathrm{He}$ asserted that in Hinduism issues of marital rights were to be seen as religious or social duties which were usually enforced by the caste community and could not be seen to be under the jurisdiction of Civil Courts.

Bhikaji's counsel, in turn, argued that by giving his judgment before hearing the defence counsel, Justice Pinhey had acted on sentiment rather than law.63 They then posited a rather circular line of reasoning where they argued that while there was no direct authority for "restitution of conjugal rights" within Hindu law, there was no law forbidding it either.

Despite Telang's attempt to establish that such suits were discredited within Hindu law, the Chief Justice held that the principle of the suit turned on the issue of validity of the

61 Letter by KT Telang dated 24 April 1887 published as "The Rakhmabai Defence Fund Committee," TOI, 26 May 1887, 5.

62 Dadaji Bhikaji v Rukmabai (1886), 307.

63 "Suit by a Brahmin for the Restitution of Conjugal Rights: Dadajee Bikajee vs Rukmibai," TOI, 13 March 1886, 3. 
marriage and not necessarily on the lack of consent of the bride. "If by Hindoo law the marriage is perfectly valid, quite independent of any consent as we understand the word -- for she has been given away by her parents, and they have a right to do so -- can the court refuse to grant the relief?" 64 Here the judges' desire to uphold the validity of the infant Hindu marriage vied with their sympathy towards Hindu women who were bound in marriages that they had never consented to. Thus, the Chief Justice also noted: "No woman who has not entered the married state with her free consent should be ordered to go to her husband if she does not like it." 65

However, in the end the judges returned to the position that the validity of a Hindu marriage did not rest upon the consent of the bride or the groom. "The marriage of Hindoo children is made by their parents. The children exercise no volition." 66 The Chief Justice held that starting from Munshee Buzloor Ruheem a handful of previous cases in India had indeed established that a suit for restitution of conjugal rights could lie between the natives, whether they were Hindu or Muslim. That the gist of the notion of restitution of conjugal rights was that married persons were bound to live together, and that under Hindu law consummation was not necessary to complete a marriage. Finally, he held that: "whether the withdrawal or 'subtraction', as Blackstone terms it, be before or after consummation, there has been a violation of conjugal duty which entitles the injured party to the relief prayed." 67 The case was then remanded to the High Court for a retrial.

\footnotetext{
64 "Suit by a Hindoo," 19 March 1886.

65 "Suit by a Hindoo," 19 March 1886.

66 "Suit by a Hindoo," 19 March 1886.

67 Dadaji Bhikaji v Rukmabai (1886), 311.
} 
Since Pinhey had recently retired, the case fell to Justice Farran and was heard in March 1887 at the Bombay High Court. Coincidentally, while a lawyer, Farran had drawn Bhikaji's original plaint, a fact that Rukhmabai's counsel did not employ to raise an objection, nor did Farran use it in order to recuse himself.68 The Appellate Court had already decided that the lack of consent of a minor bride could not constitute a defence against a suit for restitution of conjugal rights. The law thus settled, the case came to rest on Bhikaji's illness and his ability to provide a suitable home for his wife. Since Bhikaji did have some means at his disposal, it was deemed that he was able to support his wife. The court ordered Rukhmabai to "go or return" to the house of Bhikaji within a month from when the judgment was given, or render herself liable to imprisonment for six months.69 As Rukhmabai and her solicitors had already made clear that she would rather go to prison than live with Bhikaji, the Court also ordered her to pay his costs for the original hearing, with the costs of appeal being borne by each party.

As we have seen above, the idea of restitution of conjugal rights was a new legal transplant into Hindu marriage law, a fact that was reiterated in the courtroom time and again. However, even though European newspapers sympathised with Rukhmabai, they lay the blame squarely, and incorrectly, on Hindu law. The Queen echoed this widespread sentiment when it noted: "The judge, unhappily, had no alternative; he was bound by his office and his oath to administer Hindoo laws..."70

\footnotetext{
68 “The case of Ruckmibai,” TOI, 4 March 1887.

69 "The case of Ruckmibai,” TOI, 4 March 1887.

70 The Hindu Lady, The Queen reprinted in TOI, 11 April 1887, 5.
} 
Rukhmabai immediately filed an appeal against Farran's judgment, with the aim of pursuing the case till the Privy Council if needed. The whole country along with the Viceroy, Lord Dufferin, was closely monitoring the situation, and the latter recognised "that it would never do to allow her to be put into prison".71 Imprisonment of an educated middle-class woman, far more so than a judgment against her, would have allowed public opinion to swing in her favour.

The case returned before Sargent and Bayley in the summer of 1888 to enforce Farran's judgment. They were also tasked with assessing whether Rukhmabai possessed separate property which would allow her to pay the costs awarded to Bhikaji. Based on an agreement suggested by "mutual friends" of Rukhmabai and Bhikaji, her counsel suggested that she pay Bhikaji 2,000 rupees within two weeks in return for his undertaking that he would not execute the decree granted by Farran or make any claim on Rukhmabai's person or property in the future. 72

Bhikaji agreed to the settlement and immediately remarried, just as the defence counsel had been urging him to do from the start of the case. 73 With financial help from her Indian and British supporters, Rukhmabai moved to London to study medicine and became India's first practicing female doctor. She continued to practice medicine in Western India till 1930, and championed social reform till her death in 1955.

\footnotetext{
71 Chandra, "Whose laws?," 189.

72 “The Last of the Rukhmabai Case," TOI, 7 July 1888, 3.

73 "Suit by a Hindoo," 19 March 1886.
} 
Our examination of Rukhmabai's interactions with the courts reveals that in this, the first case focusing on female consent and its importance to restitution of conjugal rights within Hindu marital law, all the parties involved understood "consent" as intelligent or personal consent. While there was some dispute on whether Rukhmabai was eleven or thirteen years old at the time of marriage, there was no doubt that she was over the physical age of consent set at ten under the Indian Penal Code at the time. Not to mention that when Bhikaji brought the suit against her, she was already twenty-two and well over the age of consent. Yet neither of the parties to the case or any of the judges sought to reduce the question of consent to an issue of her physical maturity alone. Instead, the question was whether or not Rukhmabai's lack of reasonable consent to her marriage by virtue of being a minor at the time of the wedding was enough to constitute a defence to the suit for restitution of conjugal rights. Unfortunately, the judges did not find in Rukhmabai's favour and the end of her case also put an end to the idea of intelligent female consent in Hindu marital law for decades to come.

\section{Rukhmabai's views on consent}

In August 1884, a few months after Bhikaji had filed his suit in the Bombay High Court, a widespread public debate was started on the issue of infant marriage in Western India. The impetus for this debate, that soon spread to the rest of the country, were two articles published by Behramji Malabari. Malabari, a Parsi journalist, author and the editor of the Indian Spectator known for his activism for social reform, had published his "Notes" on "Infant Marriage in India" and "Enforced Widowhood" to decry the ills of child marriage 
This is the accepted manuscript of an article published by Cambridge University Press in Law and History Review. Available on line: https://doi.org/10.1017/S0738248020000024

Accepted version downloaded from: http://eprints.soas.ac.uk/32594/

within Hinduism. The two pamphlets were "journalistic appeals for sympathy and action" 74 aimed at both the state and society at large. They relied on invoking reform through emotional reactions rather than a discussion of relevant laws or legal cases, though in later responses Malabari did write about Rukhmabai's case. These pamphlets touched a nerve amongst reformists and traditionalists alike and provoked extensive debate. 75 They elicited at least 200 formal replies and started a public discussion on these themes. The responses came from "virtually every social reformer in the county, supporters of orthodoxy of all descriptions, medical men, lawyers, princes, government servants, British administrators in their private capacities, scholars; and from public bodies, some long established and some created for the purpose of supporting or attacking the proposals."76 Malabari later took his campaign to Britain, and in 1890 published An Appeal from the Daughters of India. 77

Thus, outside the courtroom the debate on infant marriage came to be largely dominated by two sides: the traditionalists who did not think any change needed to be made in Hindu marital law, and the reformists who argued for raising the age of marriage. However, the only idea of female consent that the reformists focused on was a physical age

74 Heimsath, Indian Nationalism and Hindu Social Reform, 151.

75 Behramji Malabari, Infant Marriage and Forced Widowhood in India: Being a collection of opinions, for and against, received by Mr Behramji M Malabari, from Representative Hindu Gentlemen and official and other authorities (Bombay: Voice of India, 1887).

76 Heimsath, Indian Nationalism and Hindu Social Reform, 152.

77 Behramji Malabari, An Appeal from the Daughters of India (London: Farmer and Sons, 1890). 
This is the accepted manuscript of an article published by Cambridge University Press in Law and History Review. Available on line: https://doi.org/10.1017/S0738248020000024

Accepted version downloaded from: http://eprints.soas.ac.uk/32594/

of consent.78 Even Malabari, noted that the fact that such a marriage restricts the "exercise of free will" was not his main complaint. For he argued that "parental control is necessary and mostly beneficial even when the parties have come to years of discretion."79 Thus, Malabari's objections to infant marriage came to focus on the physical and economic repercussions of an early marriage, namely "sickly children", poverty, enforced widowhood, and "over population and consequent disturbances”. And though he campaigned for an increase in the minimum age of consent, he placed this age at 12 for girls, well below the age of 15 suggested by Rukhmabai.

The other public champion of Rukhmabai, The Times of India, also distanced itself from the consent-based argument. The editorial that accompanied her first letter took care to establish that she was the right kind of feminist - "The 'Hindu Lady' does not belong to the 'Shrieking Sisterhood' but she certainly writes out of the bitterness of her heart." And though supportive of her cause, the editorial swiftly moved away from Rukhmabai's position of women being allowed to gain an education before marriage, to a position that imagined the female figure as body and not intellect. "The strength, both of mind and body, is sapped by these early marriages. The children [produced through such a marriage] either die off like weakly seedlings, or grow up without vigour. These women, as we have said on a previous occasion, lose their beauty at twenty, are long past their prime at thirty, and old at forty." 80

${ }_{78}$ For a further discussion on these positions see Kosambi, "Girl-Brides and Socio-Legal Change".

79 Malabari, "Infant marriage in India," 1.

80 "Editorial Article 1," TOI, 26 June 1885. 
This is the accepted manuscript of an article published by Cambridge University Press in Law and History Review. Available on line: https://doi.org/10.1017/S0738248020000024

Accepted version downloaded from: http://eprints.soas.ac.uk/32594/

In contrast to these views Rukhmabai's turn to "choice" marks a strong departure from the usual arguments on female consent in colonial India. While the infant marriage debate was swirling in the public sphere, Rukhmabai wrote two letters to the editor of The Times of India under the pseudonym "A Hindu Lady" titled "Infant Marriage and Enforced Widowhood" and "Enforced Widowhood".81 Both letters were published while the case was being heard by Pinhey. In fact, the second letter was published on the day that Pinhey delivered his judgment. Despite Latham's encouragement the Court of Appeal did not call on Rukhmabai to present her own defence in the courtroom, 82 which makes these publications the only way to recover her opinions at the time.

Malabari's influence on the debate around child marriage is clear from the title of Rukhmabai's letters to the newspaper, and she started the first letter by articulating the debt of gratitude that she and other Indian women owed to him. She also mentioned the happiness that she felt when Malabari's "Notes" were published but added that this happiness quickly faded when she realised that many Hindu men were publicly speaking against the reforms suggested.83 However, in a later article she argued that she had been writing on these issues

81 For a close examination of how Rukhmabai's writings were received in India and UK see Burton 'From Child Bride to "Hindoo Lady”, especially pp 1137 - 1142. 82 "Suit by a Hindoo," 19 March 1886.

83 Rukhmabai writing as "A Hindu Lady", "Infant Marriage and Enforced Widowhood," TOI, 26 June $1885,4$. 
This is the accepted manuscript of an article published by Cambridge University Press in Law and History Review. Available on line: https://doi.org/10.1017/S0738248020000024

Accepted version downloaded from: http://eprints.soas.ac.uk/32594/

for the vernacular press long before Malabari had brought them into the limelight in the English newspapers. 84

Through the letter, Rukhmabai attempted to speak directly to her "English readers", the government and the leaders of her community. She noted that the institutions of infant marriage and enforced widowhood effected all Hindus regardless of class or age but singled out women as their greatest victims. Speaking of the former she plaintively stated, "this evil custom has destroyed the happiness of my life in such a pitiable manner". However, as yet unsure of the response that she would receive, and keeping in mind the diversity of her audience, Rukhmabai did not delve too much on her personal case, nor did she frame her objection to child marriage on the basis of lack of "consent" but appealed instead to her readers' desire for social reform. She focused on the ways in which an early marriage could restrict the Hindu woman and lead to "the loss of mental and physical freedom".

Rukhmabai's objection also placed particular emphasis on the way that child marriage restrained a girl-bride's access to education, and how it had kept her personally from what she desired the most, i.e. "study and mental cultivation". Thus, she noted: "Our condition, therefore, cannot, sir, be improved, unless the practice of early marriage is abolished and higher female education is largely disseminated." Based on this, Rukhmabai recommended

\footnotetext{
84 Rukhmabai, “Rukhmabai's reply to Dadajee's 'Exposition',” TOI, 29 June 1887, 5. For an examination of other contemporary women's writings on age of context in the vernacular press in Bombay see Anagol, The Emergence of Feminism in India 1850-1920, Ch 6.
} 
This is the accepted manuscript of an article published by Cambridge University Press in Law and History Review. Available on line: https://doi.org/10.1017/S0738248020000024

Accepted version downloaded from: http://eprints.soas.ac.uk/32594/

raising the minimum age of marriage to 15 for girls and 20 for men, to give both sexes enough time to acquire a proper education. 85

While this lengthy letter had aimed to tackle Rukhmabai's thoughts on both child marriage and enforced widowhood, she did not have the space to discuss the latter issue and returned to the subject in her second letter. Published three months after the first, in "Enforced Widowhood" Rukhmabai drew the attention of her readers to the plight of all Hindu women who were culturally barred from remarrying. While doing so she paid special attention to the misery of the "child-widow" who married in infancy and may never even have lived with her husband, but upon his death was reduced to being shunned by her community.86

While in her trial the AG continued to try and establish -- as it turned out, unsuccessfully -- lack of consent as a defence against a suit for restitution of conjugal rights in infant Hindu marriages, Rukhmabai's first publicly aired views on the issue appeared in The Times in 1887. She had expressed these views in a letter to the sister of the bishop of Carlisle, and the latter had forwarded it along with a cover letter to the newspaper. In this letter, published soon after Justice Farran delivered his judgment at the Bombay High Court, Rukhmabai sought to explicitly highlight the importance of the age of the bride at the time of marriage and her right to exercise intelligent consent while choosing her husband. She further

85 Rukhmabai, "Infant Marriage and Enforced Widowhood". 86 Rukhmabai writing as "A Hindu Lady", "Enforced Widowhood," TOI, 19 September $1885,4$. 
This is the accepted manuscript of an article published by Cambridge University Press in Law and History Review. Available on line: https://doi.org/10.1017/S0738248020000024

Accepted version downloaded from: http://eprints.soas.ac.uk/32594/

sought to argue that these considerations were not foreign concepts but precepts that could be found in "Sastras and the Hindoo laws".

Rukhmabai was not the first woman to try and reconfigure religion from the source of her oppression to the tool for her emancipation. Indeed, as Anagol notes: "In what appears to be a global phenomenon, religion has been the principal arena in which women have fashioned their weapons of opposition, providing them with their chief passage to feminist consciousness." 87 This was also true in the colonial era in India, where the colonial social order, often inadvertently, "opened up limited social, material, and legal opportunities for native women, allowing them some mobility within positions of relative powerlessness." 88 Though in the social hierarchy the native woman was the least powerful, she was not, in fact, powerless. For many Indian women including Rukhmabai, the battle for greater rights was fought equally through the discourses of religion and law, and especially in the spaces in which they both overlapped.

While offering her own interpretation of Hindu religious texts, Rukhmabai urged the colonial authorities to be true to her emancipatory reading of them. According to her, the Shastras stated that girls "should be allowed to marry when they become of age and with their own choice, though nothing has been said for their education. We find in ancient history

87 Anagol, "Feminist Inheritances and Foremothers," 525.

88 Durba Ghosh, Sex and the Family in Colonial India: The Making of Empire (Cambridge: Cambridge University Press, 2006), 16. 
This is the accepted manuscript of an article published by Cambridge University Press in Law and History Review. Available on line: https://doi.org/10.1017/S0738248020000024

Accepted version downloaded from: http://eprints.soas.ac.uk/32594/

marriages taking place between the boys and girls of mature ages and with their own liking.

But these good laws have ceased to be observed..." 89

She also lamented that due to "ignorance and superstition" Hindus had introduced caste endogamy, thus reducing the pool of suitable matches, a problem further exacerbated by the fact that the parents of the child bride and groom "pay greater attention to the respectability and standing of the family than to the personal attributes of the child itself." In this letter, far more so than the previous letters, she bared her thoughts on her own marriage and the "distaste" that she felt for it and the habits of her husband.

Rukhmabai returned to this theme in her response to Bhikaji's "Exposition" published soon after in The Times of India. Here, she made clear that the choice to refuse to join Bhikaji in conjugality was hers alone: "Having watched his movements for the last five or six years, I gave him up as irreclaimably lost and made up my mind to wash my hands of him forever." 90 She also explained that far from keeping her away from Dadaji in order to control her property, her mother and grandfather were more amenable to the couple's reconciliation and had to be brought around to her point of view.

Through these letters Rukhmabai became one of the first, and by far the most wellknown, Indian woman of the nineteenth century who publicly asserted the right of Hindu women to choose their own husbands. The fact the Rukhmabai wrote in English and thus

89 Rukhmabai, "A Jubilee for the Women of India". 90 “Rukhmabai’s reply to Dadajee's 'Exposition””. 
This is the accepted manuscript of an article published by Cambridge University Press in Law and History Review. Available on line: https://doi.org/10.1017/S0738248020000024

Accepted version downloaded from: http://eprints.soas.ac.uk/32594/

directly spoke to her chosen audience of sympathetic Britons as well as colonial officers and educated men in India further propelled her to fame.

\section{Conclusion}

It is clear from a close examination of the case that Rukhmabai, Latham and Pinhey were attempting to change the way consent was understood within Hindu marital law by arguing that lack of consent should be allowed as a defence against suits for restitution of conjugal rights. Not only that, through her stress on education and desire for age of consent to be raised to 15 to allow the girl to partake an education Rukhmabai does not just want consent to be a pre-condition to a valid marriage, but informed or intelligent consent. However, by accepting that Hindu marriage was a sacrament and not a contract, and that the courts could not just grant a suit for restitution of conjugal rights within Hindu marriage, but could go so far as to institute such rights against a non-consenting wife in an unconsummated marriage, the Appellate Court effectively removed the idea of intelligent consent from the legal understanding of Hindu marriage for decades to come.

Following an official inquiry in response to Malabari’s campaign, in 1886 an attendant Resolution of the Viceroy in Council stated the government view that no administrative or legislative action needed to be taken on the issue.91 Indeed, nothing else was done till Phulmonee Dasi's death in 1889 led to a renewed debate on the minimum age of consent. The debate about consent within an infant marriage turned instead into a debate on the ills of premature consummation of a valid marriage. This, in turn, led to the passing of the Age of Consent Act 1891 where even the architect of the Act, Andrew Scoble, noted that

\footnotetext{
91 Heimsath, Indian Nationalism and Hindu Social Reform, 158.
} 
This is the accepted manuscript of an article published by Cambridge University Press in Law and History Review. Available on line: https://doi.org/10.1017/S0738248020000024

Accepted version downloaded from: http://eprints.soas.ac.uk/32594/

though girls were probably not mentally competent enough to give consent before the age of fourteen, the minimum age of consent was to be determined by supposed physical competency alone.92 The age of consent was thus fixed at twelve and continued to remain so well into the twentieth century.

92 Abstract of the Proceedings of the Council of the Governor General of India assembled for the purpose of making Laws and Regulations 1891, vol 30 (Calcutta: Government Printing, 1892) 12. 